\title{
Project Performance vs. Use of Technologies at the Work Function Level
}

\author{
by
}

\author{
James T. O'Connor ${ }^{1}$ and Li-Ren Yang ${ }^{2}$
}

\begin{abstract}
An industry-wide survey was used to collect project data from more than 200 capital facility projects on the issue of technology usage at the work function (WF) level and overall project success. Findings pertaining to associations between project success and technology usage at the work function level are discussed. The project success variables analyzed include project schedule success and project cost success.

Research hypotheses analyzed in this study are presented as follows: 1) High-Tech WFs vs. Project Schedule Success, 2) Low-Tech WFs vs. Project Schedule Failure, 3) High-Tech WFs vs. Project Cost Success, and 4) Low-Tech WFs vs. Project Cost Failure. Project schedule success or failure is particularly leveraged with technology usage or lack thereof for developing scope of work, acquiring \& responding to shop drawings, communicating Requests for Information \& response, providing feedback about cost \& schedule impacts from changes, using as-built information in operator training, and updating as-built drawings. Project cost success or failure is particularly leveraged with technology usage or lack thereof for monitoring facility energy consumption.
\end{abstract}

KEYWORDS: cost success, schedule success; technology usage; work function; work function characteristics

\section{INTRODUCTION}

\subsection{Study Background, Study Objectives, and Scope Limitations}

This paper presents findings pertaining to associations between project success and technology usage at the work function level. The data upon which these statistics are based were collected from more than 200 capital facility projects in the lower 48 states of the U.S. between October 1998 and August 1999.

Technology usage metrics analyzed include those for High- and Low-Tech WFs. HighTech and Low-Tech WFs are associated with the highest levels of technology utilization (Level 3) and the lowest levels of technology utilization (Level 1) in executing work functions for the subject project, respectively.

The project success variables analyzed include final performance of the projects in terms of schedule and cost success. With respect to the schedule success variable, schedule success is defined to have occurred when the actual project completion date was significantly earlier than planned. Schedule failure occurs when the actual project completion date was significantly later than planned. For the cost success variable, cost success is defined to have occurred when the total installed cost was significantly under authorized budget. Cost failure occurs when the total installed cost was significantly over authorized budget.

\subsection{Research Hypotheses}

Research hypotheses analyzed in this study are detailed as follows: 1) Higher levels of project schedule success are associated with certain WFs when High-Tech approaches are applied to those WFs, 2) Lower levels of project schedule success are associated with certain WFs when Low-Tech approaches are applied to those WFs, 3) Higher levels of

project cost success are associated with certain

\footnotetext{
${ }^{1}$ Professor, Department of Civil Engineering, ECJ 5.2, The University of Texas, Austin, TX 78712; PH 512-471-4645; jtoconnor@mail.utexas.edu

${ }^{2}$ Graduate Research Assistant, Department of Civil Engineering, ECJ 5.2, The University of Texas, Austin, TX 78712; 1ry@mail.utexas.edu
} 
WFs when High-Tech approaches are applied to those WFs, and 4) Lower levels of project cost success are associated with certain WFs when Low-Tech approaches are applied to those WFs.

\subsection{Methodology}

Salient aspects of the research methodology are presented as follows:

- Small projects $(<\$ 5 \mathrm{mil}$.) were excluded from the analysis.

- High-Tech/High Schedule Success WFs involve significantly more technology usage and are associated with a higher rate of schedule success.

- Low-Tech/Low Schedule Success WFs involve significantly less technology usage and are associated with a lower rate of schedule success.

- High-Tech/High Cost Success WFs involve significantly more technology usage and are associated with a higher rate of cost success.

- Low-Tech/Low Cost Success WFs involve significantly less technology usage and are associated with a lower rate of cost success.

- Project schedule success or failure is particularly leveraged with technology usage or lack thereof for the work functions pertaining to both HighTech/High Schedule Success WFs and Low-Tech/Low Schedule Success WFs.

- Project cost success or failure is particularly leveraged with technology usage or lack thereof for the work functions pertaining to both HighTech/High Cost Success WFs and LowTech/Low Cost Success WFs.

\section{SCHEDULE SUCCESS FINDINGS}

\subsection{High-Tech/High Schedule Success WFs}

Table 1 presents High-Tech WF descriptive statistics according to project schedule performance. High-Tech/High Schedule Success WFs involve significantly more technology usage and are associated with a higher rate of schedule success, so HighTech/High Schedule Success WFs include the following work functions (presented in order of significance):

- Develop scope of work

- Model user's process

- Conduct needs analysis

- Prepare milestone schedule

- Train facility operators

- Use as-built information in operator training

- Provide feedback about cost and schedule impacts from changes

- Earthwork \& grading

- Acquire and respond to shop drawings

- Develop detailed construction schedule

- Communicate Requests for Information $\&$ response

\section{$\underline{2.2 \text { Low-Tech/Low Schedule Success WFs }}$}

Table 2 presents Low-Tech WF descriptive statistics according to project schedule performance. Low-Tech/Low Schedule Success WFs involve significantly less technology usage and are associated with a lower rate of schedule success, so LowTech/Low Schedule Success WFs include the following work functions (presented in order of significance):

- Provide feedback about cost and schedule impacts from changes

- Link between supplier cost quotes and cost estimate

- Request facility maintenance or modifications

- Update as-built drawings

- Use as-built information in operator training

- Develop scope of work

- Submit contractor's request for payment

- Provide elevated work platform

- Acquire and respond to shop drawings

- Detect physical interferences

- Acquire and record material lab test results

\section{COST SUCCESS FINDINGS}

\subsection{High-Tech/High Cost Success WFs}


Table 3 presents High-Tech WF descriptive statistics according to project cost performance. High-Tech/High Cost Success WFs involve significantly more technology usage and are associated with a higher rate of cost success, so High-Tech/High Cost Success WFs include the following work functions (presented in order of significance):

- Monitor facility energy consumption

- Monitor environment impact from operations

- Fabricate roof trusses

- Design HVAC systems

- Design electrical systems

- Monitor equipment operations

- Conduct needs analysis

- Track the inventory of materials on site

- Prepare floor plans

- Link between quantity survey and cost estimate

- Model user's process

\subsection{Low-Tech/Low Cost Success WFs}

Table 4 presents Low-Tech WF descriptive statistics according to project cost performance. Low-Tech/Low Cost Success WFs involve significantly less technology usage and are associated with a lower rate of cost success, so Low-Tech/Low Cost Success WFs include the following work functions (presented in order of significance):

- Use as-built information in operator training

- Update as-built drawings

- Track design progress

- Document budget assumptions

- Train facility operators

- Providing feedback about cost and schedule impacts from changes

- Update as-built drawings

- Owner payment to contractor

- Monitor facility energy consumption

\section{WORK FUNCTION CHARACTERISTICS}

Additional analyses of the data are on going and pertain to Work Function Characteristics
(WFCs). WFCs are differentiae that characterize the 68 work functions. A total of 31 WFCs based on 6 categories (i.e., WF procedures, Time/Space/Cost, Information \& data, Management, WF product, and Human resource) were developed by O'Connor and Won to classify work functions by their attributes. WFC analysis reveals characteristics common to a specific work function group. This approach helps explain why different levels of technology usage exist and why specific technologies and tools are in more demand

- Details associated with WFCs and discussion regarding these analyses are included in Won's dissertation.

\section{CONCLUSIONS}

\subsection{Analysis Results for Schedule Success}

Presented in order of significance, HighTech/High Schedule Success WFs include the following work functions:

- Develop scope of work

- Model user's process

- Conduct needs analysis

- Prepare milestone schedule

- Train facility operators

- Use as-built information in operator training

Presented in order of significance, LowTech/Low Schedule Success WFs include the following work functions:

- Provide feedback about cost and schedule impacts from changes

- Link between supplier cost quotes and cost estimate

- Request facility maintenance or modifications

- Update as-built drawings

- Use as-built information in operator training

- Develop scope of work

Attention should be paid to the work functions pertaining to both High-Tech/High Schedule Success WFs and Low-Tech/Low Schedule Success WFs. Project schedule success or failure is particularly leveraged with technology usage or lack thereof for these work functions: 
- Develop scope of work

- Acquire and respond to shop drawings

- Provide feedback about cost \& schedule impacts from changes

- Use as-built information in operator training

\subsection{Analysis Results for Cost Success}

Presented in order of significance, HighTech/High Cost Success WFs include the following work functions:

- Monitor facility energy consumption

- Monitor environment impact from operations

- Fabricate roof trusses

- Design HVAC systems

- Design electrical systems

- Monitor equipment operations

- Conduct needs analysis

- Track the inventory of materials on site

Presented in order of significance, LowTech/Low Cost Success WFs include the following work functions:

- Use as-built information in operator training

- Update as-built drawings

- Track design progress

- Document budget assumptions

Project cost success or failure is particularly leveraged with technology usage or lack thereof for the work function "Monitor facility energy consumption."

\section{RECOMMENDATIONS FOR FUTURE RESEARCH}

Recommendations for future study are offered:
- Work function characteristics associated with High-Tech/High Schedule Success WFs, Low-Tech/Low Schedule Success WFs, High-Tech/High Cost Success WFs, and Low-Tech/Low Cost Success WFs may help further explain project success.

- Any future similar survey should involve expansion of assessment levels from 3 to 4 in order to improve resolution of estimates of technology usage.

\section{REFERENCES}

[1] O'Connor, J. T., Kumashiro, M. E., Welch, K. A., Hadeed, S. P., Braden, K. E., and Deogaonkar, M. J. (2000). "Project- and phaselevel technology use metrics for capital facility projects." Report No.16, Center for Construction Industry Studies, University of Texas, Austin, Texas.

[2] O'Connor, J. T., and Won, S. (2001). "Work function-level technology use metrics for capital facility projects." Report No.18, Center for Construction Industry Studies, University of Texas, Austin, Texas.

[3] O'Connor, J. T., and Won, S. (2001). "Understanding Demand for Technology via Work Function Characteristics", Proc., Special Conference on Fully Integrated and Automated Project Processes, Virginia Polytechnic and State University, Blacksburg, Virginia, 13-24.

[4] O'Connor, J. T., and Yang, L. (2002). "Capital facility project success and technology usage." Report No.22, Center for Construction Industry Studies, University of Texas, Austin, Texas.

[5] Won, S. (2002). "A model for work function-based prioritization of technologies for capital projects." PhD thesis, University of Texas, Austin, Texas. 
Table 1. High-Tech WF Descriptive Statistics by Project Schedule Performance

\begin{tabular}{|c|c|c|c|c|c|}
\hline \multirow[b]{2}{*}{ ID } & \multirow[b]{2}{*}{ WF } & \multicolumn{2}{|c|}{ \% of Responses at Level 3} & \multirow[b]{2}{*}{$\Delta \%$} & \multirow[b]{2}{*}{ Rank } \\
\hline & & $\begin{array}{c}\% \text { of Projects } \\
\text { with } \\
\text { Schedule Success }\end{array}$ & $\begin{array}{c}\% \text { of Projects } \\
\text { with } \\
\text { Schedule Failure } \\
\end{array}$ & & \\
\hline 1.01 & Conduct needs analysis & 33 & 0 & 33 & 3 \\
\hline 1.02 & Develop scope of work & 36 & 0 & 36 & 1 \\
\hline 1.03 & Model user's process & 42 & 8 & 34 & 2 \\
\hline 1.05 & Prepare milestone schedule & 40 & 10 & 30 & 4 \\
\hline 3.09 & $\begin{array}{l}\text { Acquire \& respond to shop } \\
\text { drawings }\end{array}$ & 22 & 0 & 22 & 9 \\
\hline 4.01 & $\begin{array}{l}\text { Develop detailed construction } \\
\text { schedule }\end{array}$ & 33 & 11 & 22 & 9 \\
\hline 4.09 & $\begin{array}{l}\text { Communicate Requests for } \\
\text { Information \& response }\end{array}$ & 25 & 5 & 20 & 11 \\
\hline 4.10 & $\begin{array}{l}\text { Cost \& schedule impacts from } \\
\text { changes }\end{array}$ & 24 & 0 & 24 & 7 \\
\hline 5.02 & Earthwork \& grading & 24 & 0 & 24 & 7 \\
\hline 6.02 & Train facility operators & 33 & 8 & 25 & 5 \\
\hline 6.03 & $\begin{array}{l}\text { Use as-built information in operator } \\
\text { training }\end{array}$ & 33 & 8 & 25 & 5 \\
\hline
\end{tabular}

Table 2. Low-Tech WF Descriptive Statistics by Project Schedule Performance

\begin{tabular}{|c|c|c|c|c|c|}
\hline \multirow[b]{2}{*}{ ID } & \multirow[b]{2}{*}{$\mathbf{W F}$} & \multicolumn{2}{|c|}{ \% of Responses at Level 1} & \multirow[b]{2}{*}{$\Delta \%$} & \multirow[b]{2}{*}{ Rank } \\
\hline & & $\begin{array}{c}\% \text { of Projects } \\
\text { with } \\
\text { Schedule Failure } \\
\end{array}$ & $\begin{array}{c}\text { \% of Projects } \\
\text { with } \\
\text { Schedule Success } \\
\end{array}$ & & \\
\hline 1.02 & Develop scope of work & 26 & 0 & 26 & 6 \\
\hline 2.11 & Detect physical interferences & 41 & 20 & 21 & 10 \\
\hline 3.04 & $\begin{array}{l}\text { Link between supplier cost quotes } \\
\text { and cost estimate }\end{array}$ & 50 & 19 & 31 & 2 \\
\hline 3.09 & $\begin{array}{l}\text { Acquire \& respond to shop } \\
\text { drawings }\end{array}$ & 56 & 33 & 23 & 8 \\
\hline 4.10 & $\begin{array}{l}\text { Cost \& schedule impacts from } \\
\text { changes }\end{array}$ & 78 & 29 & 49 & 1 \\
\hline 4.14 & $\begin{array}{l}\text { Submit contractor's request for } \\
\text { payment }\end{array}$ & 53 & 29 & 24 & 7 \\
\hline 5.06 & Provide elevated work platform & 69 & 46 & 23 & 8 \\
\hline 5.09 & $\begin{array}{l}\text { Acquire \& record material lab test } \\
\text { results }\end{array}$ & 50 & 29 & 21 & 10 \\
\hline 6.03 & $\begin{array}{l}\text { Use as-built information in operator } \\
\text { training }\end{array}$ & 62 & 33 & 29 & 5 \\
\hline 6.07 & $\begin{array}{l}\text { Request facility maintenance or } \\
\text { modifications }\end{array}$ & 50 & 20 & 30 & 3 \\
\hline 6.08 & Update as-built drawings & 43 & 13 & 30 & 3 \\
\hline
\end{tabular}


Table 3. High-Tech WF Descriptive Statistics by Project Cost Performance

\begin{tabular}{|c|c|c|c|c|c|}
\hline \multirow[b]{2}{*}{ ID } & \multirow[b]{2}{*}{ WF } & \multicolumn{2}{|c|}{ \% of Responses at Level 3} & \multirow[b]{2}{*}{$\Delta \%$} & \multirow[b]{2}{*}{ Rank } \\
\hline & & $\begin{array}{c}\text { \% of Projects } \\
\text { with } \\
\text { Cost Success }\end{array}$ & $\begin{array}{c}\text { \% of Projects } \\
\text { with } \\
\text { Cost Failure }\end{array}$ & & \\
\hline 1.01 & Conduct needs analysis & 25 & 0 & 25 & 6 \\
\hline 1.03 & Model user's process & 21 & 0 & 21 & 11 \\
\hline 2.05 & Prepare floor plans & 44 & 20 & 24 & 9 \\
\hline 2.08 & Design electrical systems & 47 & 18 & 29 & 5 \\
\hline 2.09 & Design HVAC systems & 47 & 14 & 33 & 3 \\
\hline 3.03 & $\begin{array}{l}\text { Link between quantity survey and } \\
\text { cost estimate }\end{array}$ & 31 & 8 & 23 & 10 \\
\hline 4.06 & $\begin{array}{l}\text { Track the inventory of materials on } \\
\text { site }\end{array}$ & 25 & 0 & 25 & 6 \\
\hline 5.07 & Fabricate roof trusses & 33 & 0 & 33 & 3 \\
\hline 6.06 & Monitor equipment operations & 38 & 13 & 25 & 6 \\
\hline 6.09 & $\begin{array}{l}\text { Monitor facility energy } \\
\text { consumption }\end{array}$ & 70 & 14 & 56 & 1 \\
\hline 6.10 & $\begin{array}{l}\text { Monitor environment impact from } \\
\text { operations }\end{array}$ & 43 & 0 & 43 & 2 \\
\hline
\end{tabular}

Table 4. Low-Tech WF Descriptive Statistics by Project Cost Performance

\begin{tabular}{|c|c|c|c|c|c|}
\hline \multirow[b]{2}{*}{ ID } & \multirow[b]{2}{*}{ WF } & \multicolumn{2}{|c|}{ \% of Responses at Level 1} & \multirow[b]{2}{*}{$\Delta \%$} & \multirow[b]{2}{*}{ Rank } \\
\hline & & $\begin{array}{c}\text { \% of Projects } \\
\text { with } \\
\text { Cost Failure } \\
\end{array}$ & $\begin{array}{c}\text { \% of Projects } \\
\text { with } \\
\text { Cost Success } \\
\end{array}$ & & \\
\hline 2.10 & Document budget assumptions & 36 & 12 & 24 & 4 \\
\hline 2.14 & Track design progress & 42 & 17 & 25 & 3 \\
\hline 4.10 & $\begin{array}{l}\text { Cost \& schedule impacts from } \\
\text { changes }\end{array}$ & 75 & 55 & 20 & 6 \\
\hline 4.13 & Update as-built drawings & 50 & 30 & 20 & 6 \\
\hline 4.15 & Owner payment to contractor & 63 & 43 & 20 & 6 \\
\hline 6.02 & Train facility operators & 63 & 40 & 23 & 5 \\
\hline 6.03 & $\begin{array}{l}\text { Use as-built information in operator } \\
\text { training }\end{array}$ & 67 & 40 & 27 & 1 \\
\hline 6.08 & Update as-built drawings & 40 & 14 & 26 & 2 \\
\hline 6.09 & $\begin{array}{l}\text { Monitor facility energy } \\
\text { consumption }\end{array}$ & 29 & 10 & 19 & 9 \\
\hline
\end{tabular}

